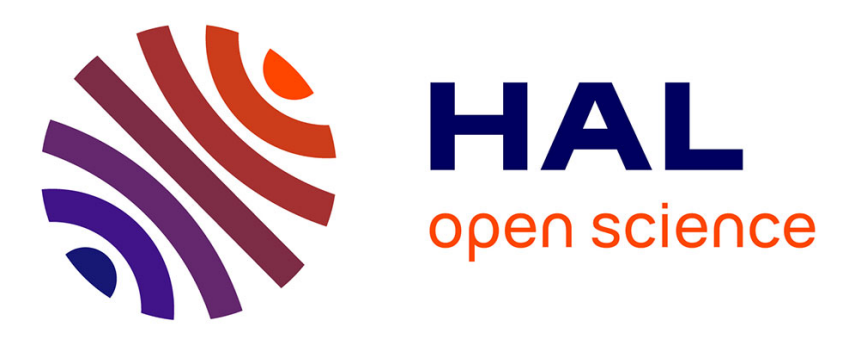

\title{
Optimisation des paramètres fréquentiels du signal d'émission appliquée à l'imagerie de contraste ultrasonore du second harmonique
}

\author{
Sébastien Ménigot, Jean-Marc Girault, Iulian Voicu
}

\section{- To cite this version:}

Sébastien Ménigot, Jean-Marc Girault, Iulian Voicu. Optimisation des paramètres fréquentiels du signal d'émission appliquée à l'imagerie de contraste ultrasonore du second harmonique. Innovation and Research in BioMedical engineering, 2012, 33 (3), pp.211-216. 10.1016/j.irbm.2012.03.003 . hal$00702965 \mathrm{v} 2$

\section{HAL Id: hal-00702965 \\ https://hal.science/hal-00702965v2}

Submitted on 2 Jan 2017

HAL is a multi-disciplinary open access archive for the deposit and dissemination of scientific research documents, whether they are published or not. The documents may come from teaching and research institutions in France or abroad, or from public or private research centers.
L'archive ouverte pluridisciplinaire HAL, est destinée au dépôt et à la diffusion de documents scientifiques de niveau recherche, publiés ou non, émanant des établissements d'enseignement et de recherche français ou étrangers, des laboratoires publics ou privés. 


\title{
Optimisation des paramètres fréquentiels du signal d'émission appliquée à l'imagerie de contraste ultrasonore du second harmonique
}

\section{Optimization of Frequential Parameters of Excitation Applied to Ultrasound Contrast Imaging of Second Harmonic Extraction}

\author{
Sébastien Ménigot ${ }^{\mathrm{a}}$, Jean-Marc Giraulta, Iulian Voicu ${ }^{\mathrm{a}}$ \\ ${ }^{a}$ Université François Rabelais de Tours, Inserm U 930, UMR-S930 and CNRS ERL 3106, Tours, France
}

\begin{abstract}
Many ultrasound contrast imaging techniques use the nonlinear behavior of contrast agents to enhance the contrast of medical images. They are based on the generation of harmonic frequencies when microbubbles are insonified by ultrasound waves. The frequential parameters of the transmitted ultrasound signal maximize the harmonic power of microbubbles. We propose an adaptive method which seeks automatically the optimal pulse parameters. These parameters allow us to maximise an energetic cost-function. The transmitted signal is composed of two different half-sines truncated, instead of a sinus wave composed of two identical half-sines truncated. With the used simulation model, the method can gives us a gain of $1.3 \mathrm{~dB}$ compared with the non-optimized system. Such results are interesting and encourage us to continue in this way. Mots clés : Imagerie ultrasonore, microbulle, optimisation, système adaptatif, système boucle fermée.
\end{abstract}

\section{Résumé}

De nombreuses méthodes d'imagerie de contraste ultrasonore utilisent le comportement nonlinéaire des produits de contraste, composés de microbulles, dans le but de réhausser le contraste des images échographiques. Elles sont basées sur l'utilisation des fréquences harmoniques générées par les microbulles lorsque celles-ci sont soumises à une onde ultrasonore. Les paramètres fréquentiels du signal ultrasonore transmis maximisent l'énergie harmonique des microbulles pour optimiser le contraste. Nous proposons une méthode adaptative qui recherche automatiquement les paramètres de l'onde optimale qui maximiseront une fonction de coût énergétique. Le signal d'excitation est défini par deux demi-sinusoïdes tronquées de périodes différentes en comparaison à une sinusoïde où les demi-sinusoïdes tronquées sont identiques. Avec le modèle de simulation utilisé, l'approche procure un gain de 1,3 dB par rapport à un système non optimisé. De tels résultats sont intéressants et nous encouragent à poursuivre cette piste.

Keywords : Adaptive system, closed-loop system, microbubble, optimization, ultrasound imaging.

Web page : http ://www.sciencedirect.com/science/article/pii/S1959031812000620

DOI : 10.1016/j.irbm.2012.03.003

Email addresses: sebastien.menigot@etu.univ-tours.fr (Sébastien Ménigot), jean-marc.girault@univ-tours.fr (Jean-Marc Girault), iulian.voicu@etu.univ-tours.fr (Iulian Voicu) 


\section{Introduction / Introduction}

Depuis maintenant presque deux décennies de recherche intensive dans le domaine de l'imagerie ultrasonore, les échographes proposent aujourd'hui des images dont la qualité en termes de sensibilité, contraste et résolution, ne cesse d'augmenter. Pour apporter des informations qualitatives complémentaires aux informations physiologiques et pathologiques [1], les cliniciens ont recours à l'injection intraveineuse de produits de contraste ultrasonore à base de microbulles [2]. Ces microbulles possèdent la propriété particulière de générer des composantes harmoniques de l'onde ultrasonore transmise bien plus intenses que celles générées par les tissus mous lorsque le niveau de pression de l'onde émise est faible [3, 4]. Ce phénomène est déjà bien compris puisqu'il s'explique à partir des équations de la dynamique non-linéaire de la microbulle [5]. Cette propriété est à l'origine de l'augmentation du contraste.

Plusieurs méthodes d'imagerie ont été proposées pour essayer d'améliorer le contraste. Certaines sont des post-traitements comme par exemple l'imagerie du second harmonique [6], l'imagerie sous-harmonique [7], l'imagerie superharmonique [8] ou la correction de l'atténuation [9]. D'autres sont des techniques de codage discret ou continu de l'amplitude, de la phase ou encore de la fréquence de l'onde ultrasonore transmise. Elles utilisent les différences des signatures acoustiques nonlinéaires des microbulles et du tissu, comme par exemple l'inversion d'impulsions [10], la modulation d'amplitude [11], la modulation de phase et d'amplitude [12, 13], la soustraction d'impulsions $[3,14]$ ou l'imagerie harmonique par chirp [4].

Le contraste, communément appelé $C T R$ pour Contrast to Tissue Ratio, défini par l'équation 1, est le rapport entre l'énergie harmonique $E_{b}$ rétrodiffusée par les microbulles et l'énergie harmonique $E_{t}$ rétrodiffusée par le
Since now almost two decades of intensive research in the field of ultrasound imaging, ultrasound scanners now offer images whose quality about sensitivity, contrast and resolution, continues to increase. To provide complementary qualitative information to the physiological and pathological information [1], clinicians use the intravenous injection of contrast agents based on microbubble [2]. These microbubbles have the particular property of generating harmonic components of the transmitted ultrasound wave, much more intense than those generated by the soft tissues, when the pressure level of the transmitted wave is low $[3,4]$. This phenomenon is already well understood since it can be explained from the equations of the nonlinear microbubble dynamics [5]. This property is at the origin of the increase in contrast.

Several imaging methods have been proposed to try to improve the contrast. Some are post-processing such as, for example, the second harmonic imaging [6], subharmonic imaging [7], superharmonic imaging [8] and attenuation correction [9]. Others are techniques with discrete or continuous coding of the amplitude, phase or frequency of the transmitted ultrasound wave. They use the differences in the nonlinear acoustic signatures of the microbubbles and the tissue, such as the pulse inversion [10], amplitude modulation [11], phase and amplitude modulation [12, 13], pulse subtraction $[3,14]$ or chirp harmonic imaging [4].

The contrast, commonly called CTR for "Contrast to Tissue Ratio", defined by the equation 1 , is the ratio between the harmonic energy $E_{b}$ backscattered by the microbubbles and the harmonic energy $E_{t}$ backscattered by 
tissu [15] :

the tissue [15] :

$$
C T R\left(2 f_{0}\right)=\frac{E_{b}\left(2 f_{0}\right)}{E_{t}\left(2 f_{0}\right)},
$$

où $f_{0}$ est la fréquence centrale d'émission.

Aujourd'hui, le choix de la fréquence d'émission $f_{0}$ dépend du constructeur et de l'opérateur. Dans tous les cas, rien ne garantit que la valeur habituellement utilisée soit celle qui procure les meilleures performances. La question qui vient naturellement est alors : « existe-t-il un choix judicieux de la fréquence d'émission qui maximise le critère de contraste comme le $C T R$ ? »

La réponse à cette question n'est pas évidente sans une connaissance précise de la problématique. En tout état de cause, ce qui est évident, c'est que la réponse est conditionnée par la sensibilité de la fonction de contraste à maximiser avec le paramètre à faire varier au niveau de l'émission, ici la fréquence. Une étape de vérification de la dépendance de la fréquence et du contraste doit être entreprise théoriquement, en simulation ou expérimentalement.

Une solution analytique de l'optimisation de la réponse d'une microbulle a déjà été proposée par Reddy et Szeri [16]. Cette solution, issue de l'optimisation seule du numérateur du CTR ressemble grossièrement à deux demisinusoïdes tronquées (figure 1). Cette solution analytique est intéressante d'un point de vue conceptuel, toutefois elle n'est pas réaliste d'un point de vue pratique puisqu'elle nécessite, pour sa résolution, la connaissance de toutes les caractéristiques physiques du transducteur et du milieu à explorer.

Pour s'affranchir de ces connaissances trop contraignantes, une solution sous-optimale a été proposée récemment à travers des simulations et des expérimentations [17]. Dans ce travail, il a été montré que la fréquence d'émission pouvait être un paramètre de l'excitation pertinent pour optimiser l'énergie harmonique rétrodiffusée par la microbulle. En combinant les travaux [16, 17], il semble de prime abord encore possible d'améliorer le contraste en jouant where $f_{0}$ is the center frequency of transmission.

Today, the choice of the transmit frequency $f_{0}$ depends on the manufacturer and the operator. In all cases, there is no guarantee that the most commonly used value is the one that provides the best performance. The question that comes naturally is : "is there a judicious choice of the transmit frequency that maximizes the contrast criterion as the CTR?"

The answer to this question is not obvious without a precise knowledge of the problem. In any case, what is obvious is that the response is conditioned by the sensitivity of the contrast function to be maximized with the parameter to be varied at the transmission level, in this case the frequency. A step of checking the dependence of the frequency and the contrast must be undertaken theoretically, in simulation or experimentally.

An analytical solution of the optimization of the microbubble response has already been proposed by Reddy and Szeri [16]. This solution, only resulting from the optimization of the CTR numerator, looks like roughly two truncated half-sines (Fig. ref fig1). This analytical solution is interesting from a conceptual point of view, however it is not realistic from a practical point of view, since it requires, for its resolution, knowledge of all the physical characteristics of the transducer and the medium to be explored .

To overcome this too restrictive knowledge, a suboptimal solution has been proposed recently by simulations and experiments [17]. In this work, it has been shown that the transmit frequency could be a parameter of the relevant excitation to optimize the harmonic energy backscattered by the microbubble. By combining the works $[16,17]$, it seems still possible to improve the contrast by playing now on two parameters : the truncated half-sine 
maintenant sur deux paramètres : les périodes de demi-sinusoïdes tronquées $T_{1}$ et $T_{2}$ représentées en figure 1. periods $T_{1}$ and $T_{2}$ represented in Fig. Ref fig1.

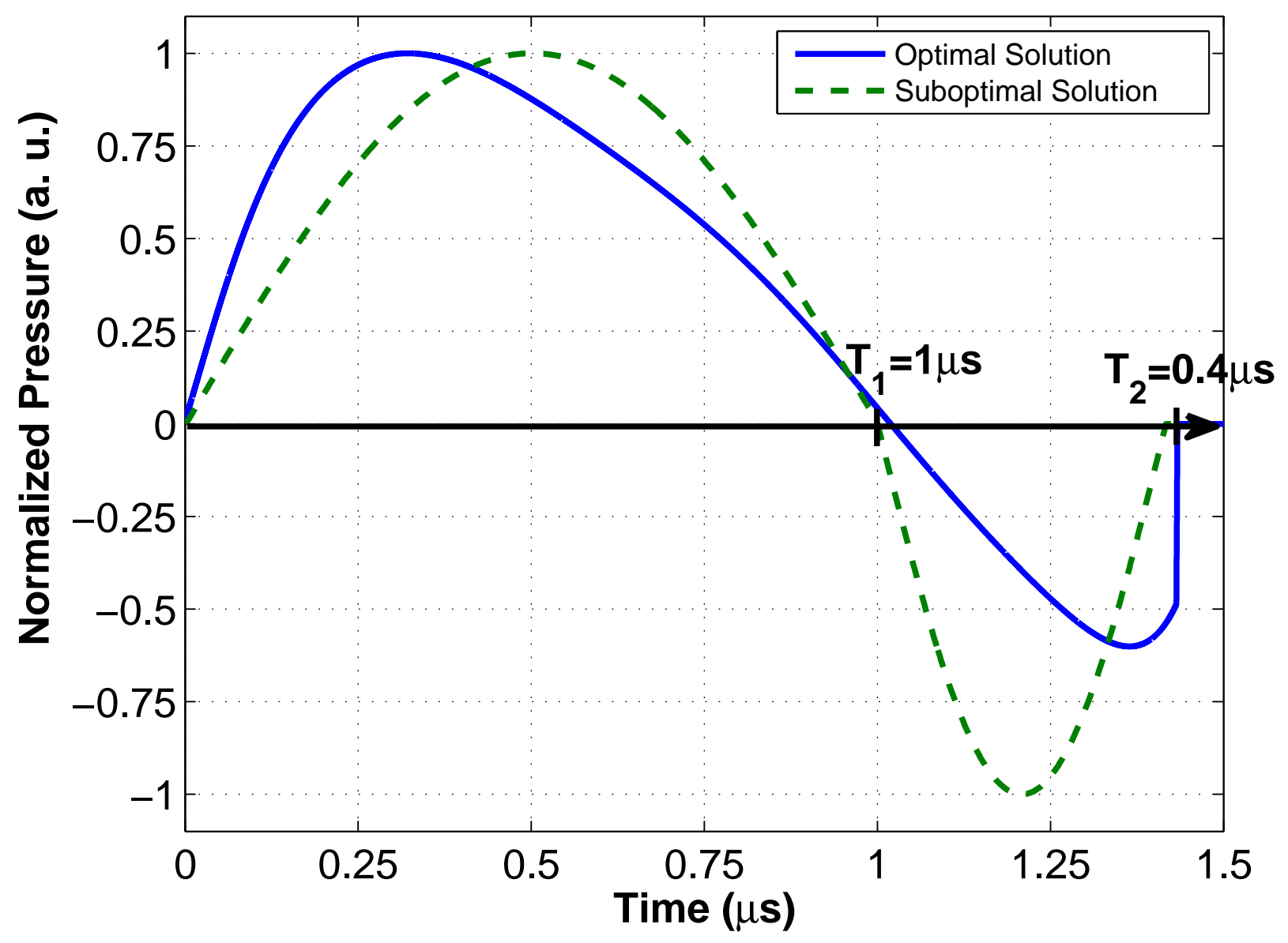

Figure 1: Un cycle de l'onde optimale calculée analytiquement [16] et un exemple d'un cycle d'une onde sousoptimale de paramètre $f_{1}=1 / T_{1}$ et $f_{2}=1 / T_{2}$.

A cycle of optimal wave calculated analytically [16] and an example of suboptimal wave with parameters $f_{1}=1 / T_{1}$ and $f_{2}=1 / T_{2}$.

L'originalité de cette méthode réside ici dans le calcul automatique des paramètres $T_{1}$ et $T_{2}$ définissant le signal d'excitation quel que soit les conditions d'utilisation. Ce calcul est obtenu par l'ajout d'un bouclage de la sortie sur l'entrée du système d'imagerie existant. Cette boucle fermée qui permet l'optimisation du contraste est assurée par un algorithme simple basé sur le gradient.
The originality of this method lies in the automatic calculation of the parameters $T_{1}$ and $T_{2}$ defining the excitation signal, whatever the conditions of use. This calculation is obtained by adding a feedback of the output to the input of the existing imaging system. This closed loop which allows the optimization of the contrast is ensured by a simple algorithm based on the gradient.

\section{Système en boucle ouverte / System in Open Loop}

Le système d'imagerie sur lequel notre étude porte est un système d'imagerie de contraste du second harmonique [6]. Le prin-
The imaging system on which our study is based is a system of second harmonic contrast imaging [6]. The principle of this imaging sys- 
cipe de ce système d'imagerie est décrit en figure 2. Il consiste à transmettre au milieu une onde ultrasonore incidente de fréquence $f_{0}$ et à recevoir les harmoniques générées par le milieu exploré à $2 f_{0}$. Il en résulte une meilleure discrimination des microbulles par rapport au tissu, ce qui se traduit par une augmentation du contraste. Détaillons maintenant les différentes fonctions principales du système. tem is described in Fig. 2. It consists in transmitting to the medium an incident ultrasound wave of frequency $f_{0}$ and receiving the harmonics generated by the medium explored at $2 f_{0}$. The microbubbles are thus better discriminated in relative to the tissue, which increases in contrast. Let us now describe the main functions of the system.

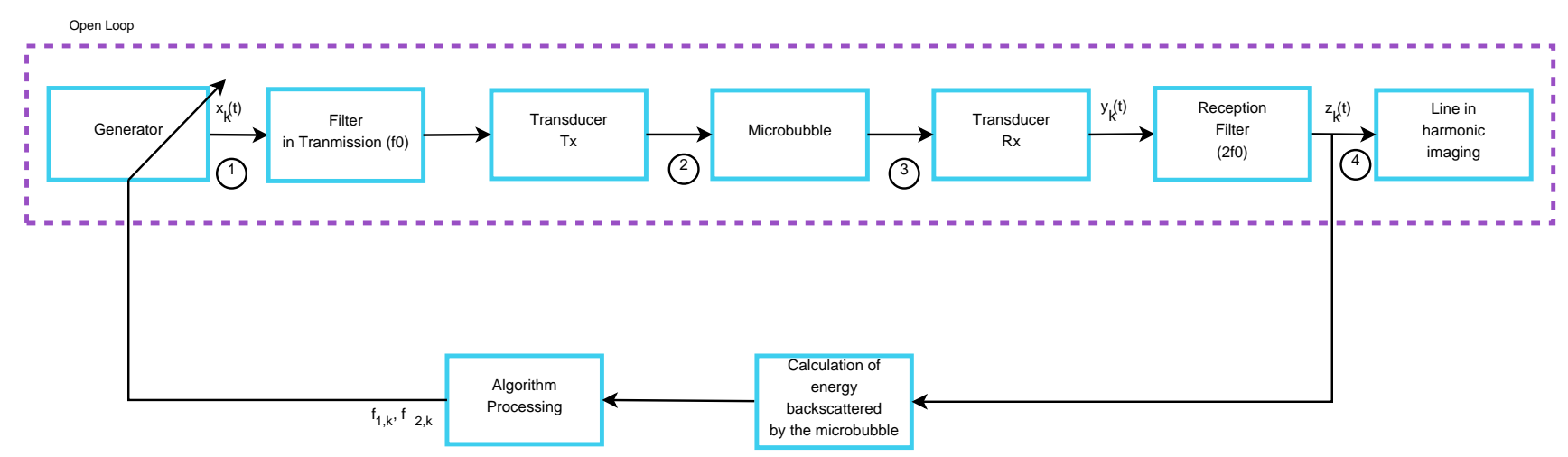

FIgURE 2: Schéma fonctionnel des simulations.Block diagram of simulations.

\subsection{Excitation et réception / Transmission and Reception}

Le signal d'excitation $x_{k}(t)$ (figure 2, point 1) est calculé numériquement avec Matlabß) (Mathworks, Natick, Massachusetts, États-Unis d'Amérique). Il est constitué de plusieurs cycles de demi-sinusoïdes (figure 1), modulés par une gaussienne tel que :
286/5000 The excitation signal $x_{k}(t)$ (Fig. 2 , point 1 ) is computed numerically with Matlab@(Mathworks, Natick, MA, USA). It consists of several cycles of half-sines (Fig. 1), modulated by a Gaussian such as :

$$
x_{k}(t)=A \cdot \exp \left[-\frac{\left(t-t_{0}\right)^{2}}{\frac{N_{c}}{\left(f_{1, k}+f_{2, k}\right)}}\right] w_{k}(t),
$$

où $t$ est le temps, $t_{0}$ est le temps lorsque la gaussienne est maximum, $A$ est l'amplitude, $N_{c}$ est le nombre de cycles de l'excitation et $f_{1, k}=1 / T_{1, k}$, respectivement $f_{2, k}=$ $1 / T_{2, k}$, sont les fréquences de la première demisinusoïde tronquée, respectivement de la seconde demi-sinusoïde tronquée, à l'itération $k$. Dans le cas d'un système boucle ouverte, l'itération $k$ est toujours la même avec $k=1$. Le signal $w_{k}(t)$ représente le signal composé des deux demi-sinusoïdes tronquées non modulées par la gaussienne et défini par l'équation 3 : where $t$ is the time, $t_{0}$ the time when the Gaussian is maximum, $A$ the amplitude, $N_{c}$ the cycle number of the excitation and $f_{1, k}=$ $1 / T_{1, k}$, respectively $f_{2, k}=1 / T_{2, k}$, are the frequencies of the first truncated half-sine and the second truncated half-sine, respectively at the iteration $k$. In the case of an open loop system, the iteration $k$ is always the same with $k=1$. The signal $w_{k}(t)$ represents the signal composed of the two truncated half-sines not modulated by the Gaussian and defined by the equation 3 :

$$
w_{k}(t)=w_{1, k}(t)-w_{2, k}(t),
$$


où $w_{1, k}(t)$, respectivement $w_{2, k}(t)$ sont les définitions des deux demi-sinusoïdes tronquées décrites dans les équations 4 et 5 . where $w_{1, k}(t)$, respectively $w_{2, k}(t)$, are the definitions of the two truncated half-sines described in the equations 4 and 5 .

$$
\left\{\begin{array}{l}
w_{1, k}(t)=\sin \left(\frac{2 \pi t}{T_{1, k}}\right) \cdot \sum_{i=-\infty}^{+\infty} \operatorname{Rect}_{\frac{T_{1, k}}{2}}\left[t-i \frac{T_{1, k}}{4}\right] \\
w_{2, k}(t)=\sin \left(\frac{2 \pi\left(t-\frac{T_{1, k}}{2}\right)}{T_{2, k}}\right) \cdot \sum_{i=-\infty}^{+\infty} \operatorname{Rect}_{\frac{T_{2, k}}{2}}\left[t-i\left(\frac{T_{1, k}}{2}+\frac{T_{2, k}}{4}\right)\right],
\end{array}\right.
$$

où $\operatorname{Rect}_{T_{l}}\left(t-T_{c}\right)$ est une fonction rectangle centrée en $T_{c}$ et de largeur $T_{l}$.

L'énergie de référence $E_{x_{\text {réf }}}$ est définie comme l'énergie à la fréquence centrale du transducteur pour un niveau de pression $A_{0}$. L'énergie de l'onde transmise $E_{w}$ est alors fixée en ajustant l'amplitude $A$ du signal : where $\operatorname{Rect}_{T_{l}}\left(t-T_{c}\right)$ is a rectangle function centred in $T_{c}$ and with a width of $T_{l}$.

The reference energy $E_{x_{r e ́ f}}$ is defined as the energy at the center frequency of the transducer for a pressure level $A_{0}$. The energy of the transmitted wave $E_{w}$ is then fixed by adjusting the amplitude $A$ of the signal :

$$
A=\sqrt{\frac{A_{0}^{2} \cdot E_{x_{r e f}}}{E_{w}} .}
$$

Le signal émis à la sortie du transducteur (point 2 en figure 2) est centré autour de $f_{0}$. En réception, le signal rétrodiffusé (point 3 en figure 2) est conjointement filtré par le transducteur et le filtre de réception (point 4 en figure 2) autour de $2 f_{0}$.

\subsection{Microbulle / Microbubble}

Les produits de contraste ultrasonores sont des microbulles de gaz circulant dans le système vasculaire. Le programme de simulation BubbleSim de Hoff [22] est utilisé pour calculer les variations du rayon d'une microbulle sous l'effet de l'onde ultrasonore. Il résout numériquement l'équation modifiée de RayleighPlesset.

Pour modéliser le comportement moyen d'un nuage de microbulles, nous supposons que la réponse de ce nuage composé de $N$ microbulles est approchée par $N$ fois la réponse d'une seule microbulle. Cette hypothèse, sans doute trop forte puisque les microbulles intéragissent entre elles, est majoritairement considérée par la communauté scientifique puisqu'elle simplifie grandement le modèle. Toutefois, notre objectif étant focalisé sur les propriétés non-linéaires du nuage de micro-
The signal transmitted at the transducer output (point 2 in Fig. 2 ) is centred around $f_{0}$. On reception, the backscattered signal (point 3 in Fig. 2) is jointly filtered by the transducer and the reception filter (point 4 in Fig. 2) around $2 f_{0}$.

Ultrasound contrast agents are microbubbles of gas circulating in the vascular system. The BubbleSim simulation program of Hoff [22] is used to calculate variations in the microbubble radius under the effect of the ultrasound wave. It solves numerically the modified equation of Rayleigh-Plesset.

To model the mean behaviour of a microbubble cloud, we assume that the response of this cloud composed of $N$ microbubbles is approximated $N$ times the response of a single microbubble. This hypothesis, probably too strong since the microbubbles interact with each other, is mainly considered by the scientific community since it greatly simplifies the model. However, our objective being focused on the nonlinear properties of the microbubble cloud, the previous hypothesis does not call 
bulles, l'hypothèse précédente ne remet pas en cause la recherche des paramètres optimaux qui maximisent l'énergie harmonique renvoyée par les microbulles interagissant ou non entre elles.

3. Optimisation du système bouclé / Opt

Le système en boucle fermée est constitué du système en boucle ouverte auquel une rétroaction est ajoutée. Comme décrit dans [16, 17], la fonction de coût à optimiser est l'énergie harmonique rétrodiffusée par la microbulle telle que : into question the search for optimal parameters which maximize the harmonic energy returned by the microbubbles interacting or not interacting with each other.

$$
\max _{f_{1}, f_{2}}\left(E_{b}\left(f_{1}, f_{2}\right)\right)
$$

où $E_{b}$ est l'énergie harmonique rétrodiffusée par la microbulle. Cette fonction de coût s'appuie principalement sur les hypothèses suivantes, elle doit :

- dépendre des paramètres $f_{1}=1 / T_{1}$ et $f_{2}=1 / T_{2}$

- être sensible à la présence des microbulles et peu sensible aux tissus non perfusés par les microbulles (ce qui est rendu possible en réduisant le niveau de pression émis);

- être, en absolue, indépendante du modèle de simulations ou des expériences réalisées ;

- être convexe dans la gamme des valeurs des paramètres $f_{1}$ et $f_{2}$ pour accoître la robustesse de l'algorithme.

En supposant la dernière hypothèse validée, un simple algorithme du gradient peut être utilisé [23]. Il est défini par la relation de récurrence suivante : where $E_{b}$ is the harmonic energy backscattered by the microbubble. This cost function is mainly based on the following assumptions :

- depend on the parameters $f_{1}=1 / T_{1}$ and $f_{2}=1 / T_{2}$

- be sensitive to the microbubble presence and not sensitive to the tissues not perfused by the microbubbles (which is made possible by reducing the pressure level transmitted);

- be, in absolute terms, independent of the simulation model or the experiments carried out;

- be convex in the range of parameter values $f_{1}$ and $f_{2}$ to increase the algorithm robustness.

Assuming the last hypothesis validated, a simple gradient algorithm can be used [23]. It is defined by the following recursion relation :

$$
F_{k+1}=F_{k}+\mu_{k}\left(\nabla E_{b}\right),
$$

où $F_{k}=\left[\begin{array}{ll}f_{1, k} & f_{2, k}\end{array}\right]^{T}$ est le vecteur des paramètres d'optimisation à l'itération $k\left({ }^{T}\right.$ est le symbole de la transposée). La fonction $\mu_{k}=$ $\left[\begin{array}{lll}\mu_{1, k} & \mu_{2, k}\end{array}\right]^{T}$ gouverne le sens et la vitesse de convergence. Pour $n=1$ et $m=2$ (ou $n=2$ et $m=1$ ) sélectionnant les paramètres, $\mu_{n, k}$ est défini par l'équation 9 : where $F_{k}=\left[\begin{array}{ll}f_{1, k} & f_{2, k}\end{array}\right]^{T}$ is the vector of the optimization parameters at the iteration $k\left({ }^{T}\right.$ is the symbol of the transpose). The function $\mu_{k}=\left[\mu_{1, k} \mu_{2, k}\right]^{T}$ leads the direction and convergence. For $n=1$ and $m=2$ (or $n=2$ and $m=1$ ) selecting the parameters, $\mu_{n, k}$ is defined by the equation 9 :

$$
\mu_{n, k}=\left\{\begin{array}{ll}
\mu_{n, k-1} & \text { si } \nabla_{n, k}\left(E_{b}\right)=\nabla_{n, k-1}\left(E_{b}\right) \\
-\frac{\mu_{n, k-1}}{2} & \text { si } \nabla_{n, k}\left(E_{b}\right) \neq \nabla_{n, k-1}\left(E_{b}\right)
\end{array},\right.
$$


où $\nabla_{n, k}\left(E_{b}\right)$ est le gradient à l'itération $k$ suivant le paramètre $n$ tel que : where $\nabla_{n, k}\left(E_{b}\right)$ is the gradient at the iteration $k$ as a function of the parameter $n$ such as :

$$
\nabla_{n, k}\left(E_{b}\right)=\frac{\partial E_{b}}{\partial f_{n}}=\frac{E_{b}\left(f_{m, k}, f_{n, k}\right)-E_{b}\left(f_{m, k-1}, f_{n, k}\right)}{f_{n, k}-f_{n, k-1}} .
$$

Afin d'évaluer l'apport de notre méthode d'optimisation par rapport à la méthode sans optimisation, le gain $G_{E}$ est calculé. Ce gain est défini par le rapport entre l'énergie harmonique rétrodiffusée pour une excitation composée de deux demi-sinusoïdes tronquées de fréquences optimales $f_{1}^{\star}$ et $f_{2}^{\star}$ et celle obtenue dans le cas standard où le signal est une sinusoïde apodisée de fréquence $f_{0}$ :
In order to evaluate the contribution of our optimization method in comparison to the method without optimization, the gain $G_{E}$ is calculated. This gain is defined by the ratio between the backscattered harmonic energy for an excitation composed of two truncated halfsines of optimal frequencies $f_{1}^{\star}$ and $f_{2}^{\star}$, and that obtained in the standard case where the signal is an apodized sine of frequency $f_{0}$ :

$$
G_{E}=\frac{E_{b}\left(f_{1}^{\star}, f_{2}^{\star}\right)}{E_{b}\left(f_{0}, f_{0}\right)} .
$$

\section{Résultats / Results}

Avant de présenter les résultats, rappelons que l'objectif global est de trouver automatiquement les fréquences $f_{1}^{\star}$ et $f_{2}^{\star}$ qui engendre l'énergie harmonique maximum rétrodiffusée par la microbulle. Pour atteindre cet objectif simplement, nous montrons empiriquement que l'énergie harmonique possède un maximum aux fréquences $f_{1}^{\star}$ et $f_{2}^{\star}$. Ensuite, une méthode itérative recherche automatiquement le couple des fréquences qui procure cet optimum.

Dans cette partie, les résultats de simulations que nous présentons ont été obtenus en considérant :

- en émission, un signal émis est filtré autour de $f_{0}=2,1 \mathrm{MHz}$ avec une bande passante de $60 \%$;

- en réception, un signal mesuré par le transducteur est filtré autour de $2 f_{0}=4,2$ $\mathrm{MHz}$ avec une bande passante de $30 \%$. Notez que le transducteur est centré autour de 2,9 $\mathrm{MHz}$ avec une bande passante de $90 \%$. À titre d'illustration, des exemples de signaux en chacun des points précisés précédemment sont représentés en figure 3. Notez, comme indiqué sur la figure 3, que l'excitation conserve son asymétrie après passage à travers le transducteur d'émission;
Before presenting the results, let us recall that the global objective is to automatically find the frequencies $f_{1}^{\star}$ and $f_{2}^{\star}$ which generates the maximum harmonic energy backscattered by the microbubble. To achieve this objective simply, we show empirically that the harmonic energy has a maximum at the frequencies $f_{1}^{\star}$ and $f_{2}^{\star}$. Then, an iterative method automatically searches for both frequencies that provides this optimum.

In this part, the results of simulations that we present have been obtained considering :

- in transmission, a transmitted signal is filtered around $f_{0}=2.1 \mathrm{MHz}$ with a bandwidth of $60 \%$;

- in reception, a signal measured by the transducer is filtered around $2 f_{0}=4.2 \mathrm{MHz}$ with a bandwidth of $30 \%$. Note that the transducer is centred around $2.9 \mathrm{MHz}$ with a bandwidth of $90 \%$. As an illustration, examples of signals at each of the points specified above are shown in Fig. 3. Note, as shown in Fig. 3, that the excitation retains its asymmetry after passing through the transmit transducer; 
les microbulles que nous avons simulés ont les propriétés de celles utilisées cliniquement. Une monocouche phospholipidique dont le module de cisaillement est de $46 \mathrm{MPa}$ [19] emprisonne de l'hexafluoride de sulfure [18]. Les microbulles ainsi constituées ont un diamètre de 4,5 $\mu \mathrm{m}[20]$ et une épaisseur de coque de $1 \mathrm{~nm}[21]$. the microbubbles that we simulated have the properties of those used clinically. A phospholipid monolayer with a shear modulus of 46 MPa [19] imprisons sulphide hexafluoride [18]. The microbubbles thus formed have a diameter of $4.5 \mu \mathrm{m}[20]$ and a shell thickness of 1 $\mathrm{nm}[21]$.
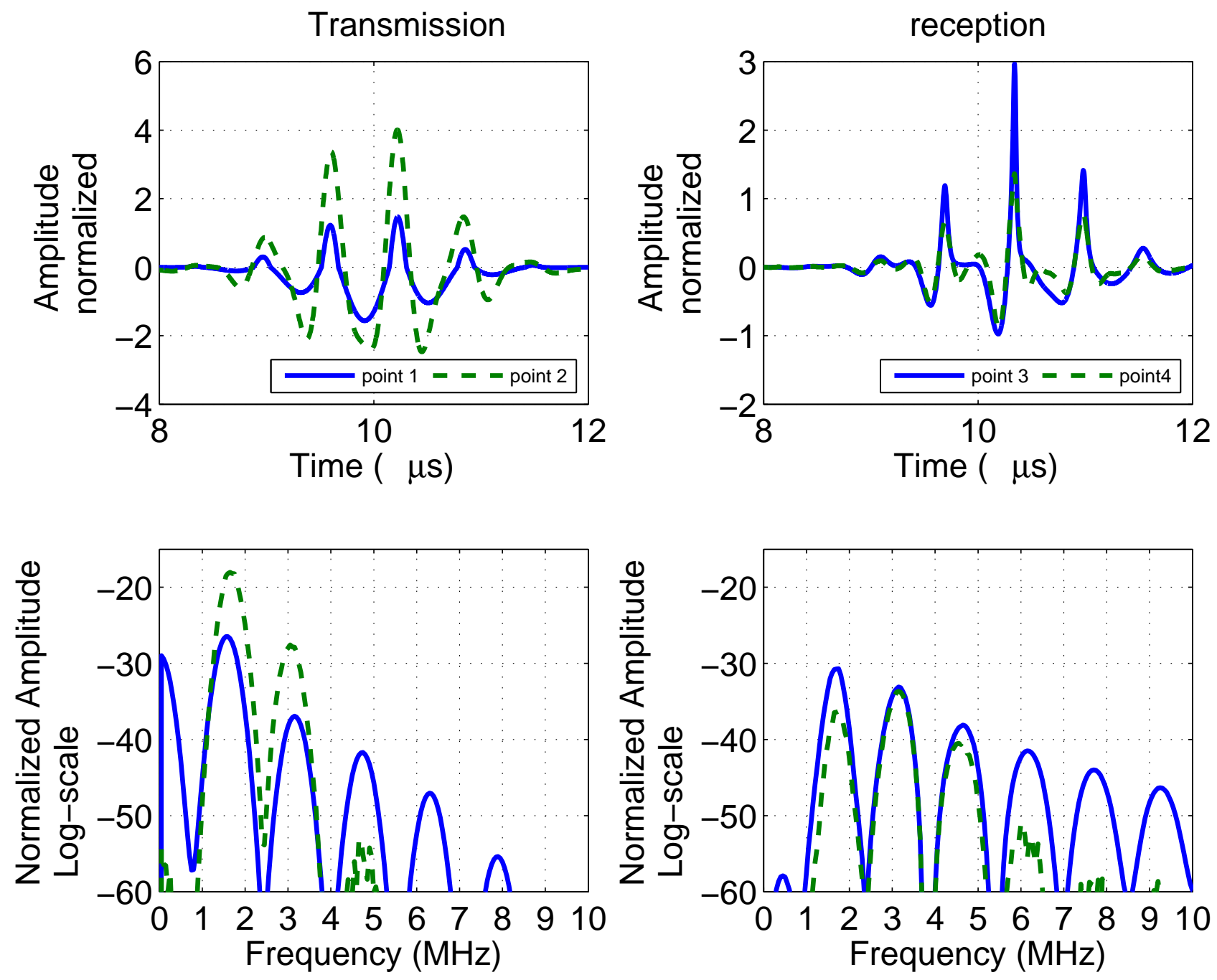

Figure 3: Exemple de signaux aux différents points notés dans le schéma fonctionnel de la figure 2. Signaux transmis avant et après filtrage autour de $f_{0}$ et leurs spectres (points 1 et 2) à gauche. Signaux reçus avant et après filtrage autour de $2 f_{0}$ et leurs spectres (points 3 et 4 ) à droite.

Example of different signals in each point of the figure 2. Transmitted signals before and after filtering centered around $f_{0}$ and their corresponding spectra (points 1 and 2) on left. Received signals before and after filtering centered around $2 f_{0}$ and their corresponding spectra (points 3 et 4 ) on right.

La première simulation, présentée en figure 4, montre l'évolution de l'énergie harmonique de la microbulle en fonction des fréquences d'émission $f_{1}$ et $f_{2}$. Ces deux fréquences sont balayées sur une gamme allant de 0,75 à $4,5 \mathrm{MHz}$ par pas de $50 \mathrm{kHz}$. Chaque
The first simulation, presented in Fig. 4, shows the evolution of the microbubble harmonic energy as a function of the transmit frequencies $f_{1}$ and $f_{2}$. These two frequencies are scanned over a range from 0.75 to $4.5 \mathrm{MHz}$ in steps of $50 \mathrm{kHz}$. Each harmonic energy backs- 
énergie harmonique rétrodiffusée par une microbulle est évaluée à partir d'une excitation d'énergie constante composée de 4 pseudopériodes et pour un niveau de pression $A_{0}$ de $240 \mathrm{kPa}$.

À partir de la figure 4, nous observons bien la présence d'un maximum, noté par le point noir en figure 4. L'énergie harmonique maximale de la microbulle est atteinte pour un couple de fréquence où $f_{1}^{\star}=3,15 \mathrm{MHz}$ est différente de $f_{2}^{\star}=1,05 \mathrm{MHz}$. Le gain $G_{E}$ est alors de $1,3 \mathrm{~dB}$. Notez que lorsque $f_{1}$ est identique à $f_{2}$, l'énergie harmonique de la microbulle est celle sur la droite tracée en noire sur la figure 4. L'énergie harmonique maximale de la microbulle mesurée sur cette droite $\left(f_{1}=f_{2}=1,55\right.$ $\mathrm{MHz}$ ) est inférieure à celle obtenue pour d'environ pour $f_{1} \neq f_{2}$ d'environ $0,6 \mathrm{~dB}$.

L'énergie maximale de la microbulle est maintenant recherchée automatiquement par l'algorithme du gradient. En figure 5b, l'énergie harmonique de la microbulle est indiquée pour chaque itération. En figure 5a, l'évolution des fréquences $f_{1}$ et $f_{2}$ au cours des itérations est reportée. Le chemin d'optimisation est également reporté avec la ligne noire en pointillé sur figure 4 . Les fréquences $f_{1}$ et $f_{2}$ convergent vers des valeurs stables au bout d'une dizaine d'itérations. L'énergie harmonique de la microbulle a atteint son maximum pour les fréquences $f_{1}^{\star}$ et $f_{2}^{\star}$. Notez que les valeurs obtenues empiriquement et automatiquement sont identiques. Le même commentaire est à faire pour le gain $G_{E}$. cattered by a microbubble is evaluated from a constant energy excitation composed of 4 pseudo-periods and for a pressure level $A_{0}$ of $240 \mathrm{kPa}$.

From Fig. 4, we observe the presence of a maximum, denoted by the black dot in Fig. 4 . The maximum microbubble harmonic energy is reached for a frequency pair where $f_{1}^{\star}=3.15$ $\mathrm{MHz}$ is different from $f_{2}^{\star}=1.05 \mathrm{MHz}$. The gain $G_{E}$ is then $1.3 \mathrm{~dB}$. Note that when $f_{1}$ is identical to $f_{2}$, the microbubble harmonic energy is that on the line drawn in black on Fig. 4. The maximum microbubble harmonic energy measured on this line $\left(f_{1}=f_{2}=1.55\right.$ $\mathrm{MHz})$ is less than that obtained for about $f_{1} \neq$ $f_{2}$ of about $0.6 \mathrm{~dB}$.

The maximum microbubble energy is now automatically searched by the gradient algorithm. In Fig. 5b, the microbubble harmonic energy is indicated for each iteration. In Fig. $5 \mathrm{a}$, the evolution of the frequencies $f_{1}$ and $f_{2}$ during the iterations is reported. The optimization path is also plotted with the dotted black line on Fig. 4. The frequencies $f_{1}$ and $f_{2}$ converge to stable values after a dozen iterations. The microbubble harmonic energy reached its maximum for the frequencies $f_{1}^{\star}$ and $f_{2}^{\star}$. Note that the values obtained empirically and automatically are identical. The same comment is to be made for the gain $G_{E}$.

\section{Discussions et conclusion / Discussions and Conclusion}

Dans le cadre de l'imagerie du second harmonique, il a été montré en simulation que l'énergie harmonique optimale rétrodiffusée par les microbulles peut être obtenue automatiquement en estimant les paramètres $f_{1}^{\star}$ et $f_{2}^{\star}$. Cette optimisation est obtenue à travers l'ensemble de la chaîne d'imagerie sans les connaissances a priori des propriétés du transducteur ou du produit de contraste. Cette optimisation, obtenue par rétroaction, est d'implémentation simple. Elle permet, en quelques itérations, un choix adapté des paramètres
In the context of second harmonic imaging, it has been shown in simulation that optimal harmonic energy backscattered by microbubbles can be obtained automatically by estimating the parameters $f_{1}^{\star}$ and $f_{2}^{\star}$. This optimization is obtained through the whole imaging chain without any a priori knowledge about the properties of the transducer or of the contrast agent. This optimization, obtained by feedback, is of simple implementation. It allows a suitable choice of the parameters $f_{1}^{\star}$ and $f_{2}^{\star}$ in a few iterations. Note that these 


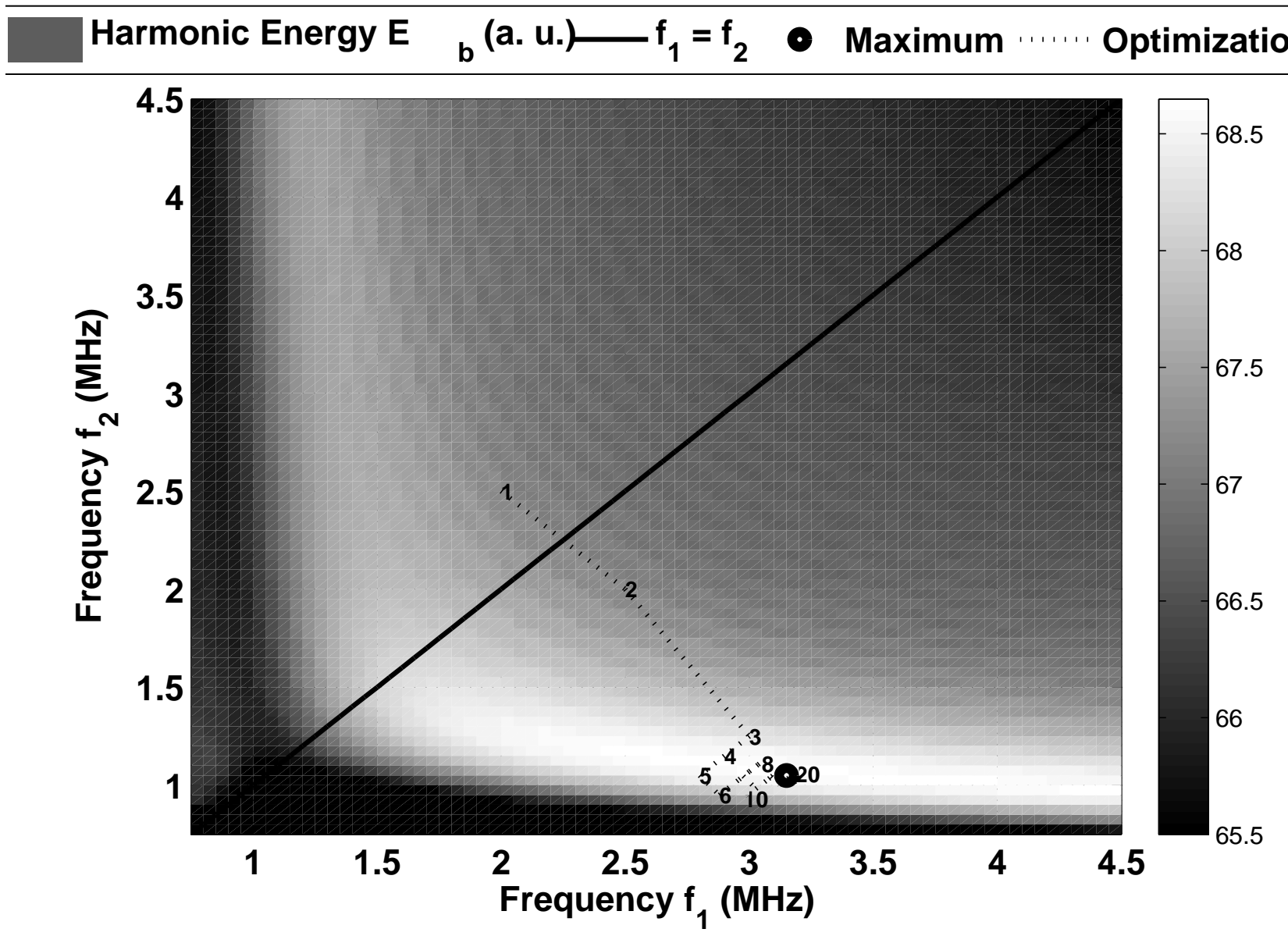

Figure 4: Simulation de l'énergie harmonique rétrodiffusée par la microbulle en fonction de la fréquence de la première demi-sinusoïde tronquée $f_{1}$ et de la seconde demi-sinusoïde tronquée $f_{2}$ pour un niveau de pression $A_{0}$ de $240 \mathrm{kPa}$. La ligne noire correspond aux cas où l'excitation est une sinusoïde où les deux demi-sinusoïdes tronquées sont identiques. Le point noir correspond au maximum déterminé empiriquement. La ligne noire en pointillé correspond au chemin de l'optimisation avec les numéros d'itération. L'unité de l'énergie est une unité arbitraire (u.a.) ayant la dimension d'une énergie et sous une échelle logarithmique.

Simulation of harmonic energy backscattered by the microbubble as a function of first half-sine truncated frequency $f_{1}$ and second half-sine truncated frequency $f_{2}$ for pressure level $A_{0}$ of $240 \mathrm{kPa}$. The black line corresponded to the case where the pulse was a sinus wave where the two half-sines truncated were identical. The black point corresponds to the maximum calculated empirically. The dashed black line corresponded to the optimization with iteration number. The energy unity was an arbitrary unity (u.a.) with a energy dimension and a log scale.

$f_{1}^{\star}$ et $f_{2}^{\star}$. Notez que ces paramètres, qui nous ont semblé être les plus simples pour décrire la solution optimale obtenue analytiquement, s'avèrent être assez judicieux puisqu'ils impactent la fonction de coût.

Cette fonction de coût est aussi sensible à la présence des microbulles puisqu'elle mesure l'énergie harmonique censée être rétrodiffusée seulement par les microbulles. En pratique, ce critère dépend aussi des harmoniques rétrodif- parameters, which seemed to us the simplest to describe the optimal solution obtained analytically, prove to be quite judicious since they impact the function of cost.

This cost function is also sensitive to the microbubble presence, since it measures the harmonic energy supposed to be backscattered only by the microbubbles. In practice, this criterion also depends on harmonics backscat- 


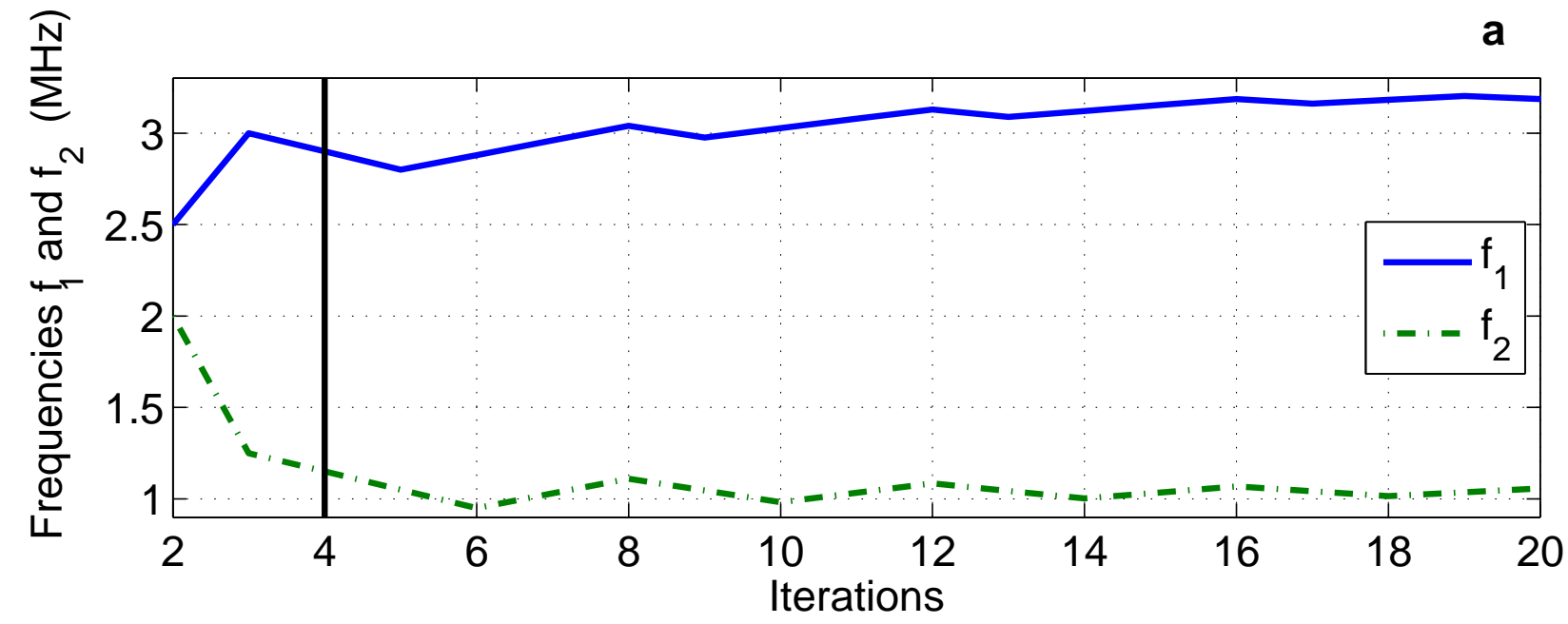

b

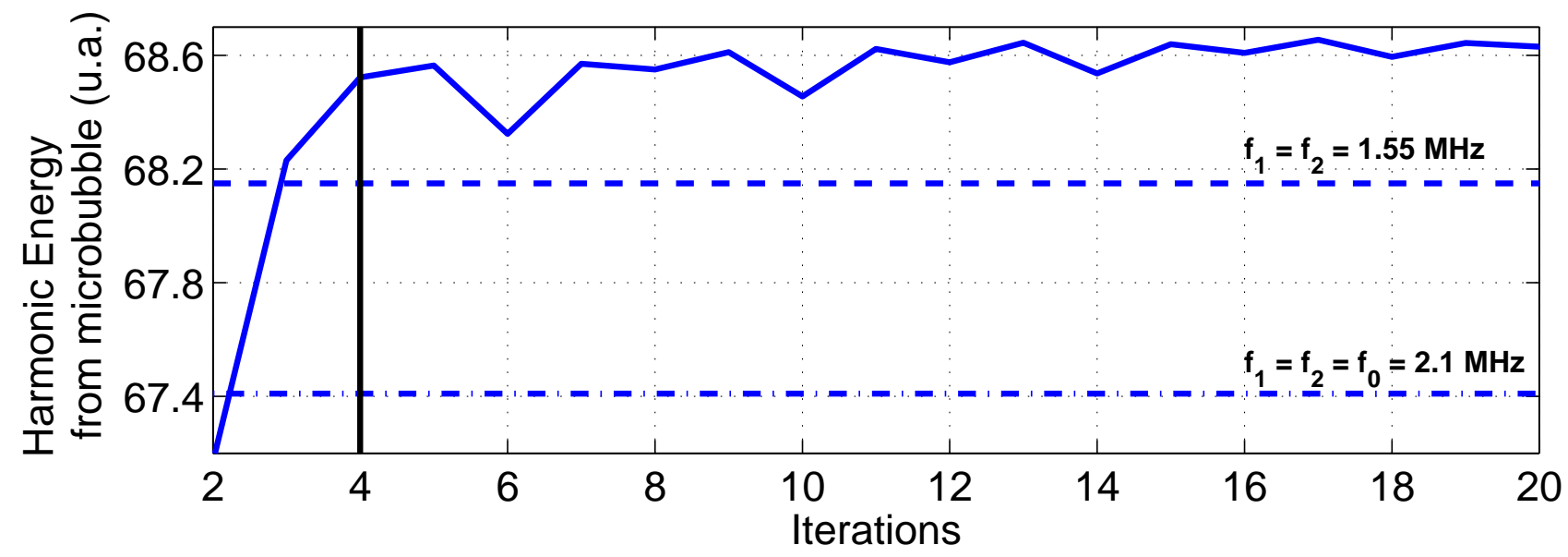

Figure 5: Simulation de l'optimisation automatique de l'énergie harmonique de la microbulle par recherche itérative des fréquences des deux demi-sinusoïdes tronquées $f_{1}$ et $f_{2}$. Le niveau de pression $A_{0}$ est de $240 \mathrm{kPa}$. La ligne en pointillé régulier correspond à l'énergie harmonique de la microbulle maximale lorsque $f_{1}$ est égal à $f_{2}$. La ligne en pointillé irrégulier est l'énergie harmonique de la microbulle lorsque le système est non-optimisé tel que $f_{1}=f_{2}=f_{0}$. L'unité de l'énergie est une unité arbitraire (u.a.) ayant la dimension d'une énergie et sous une échelle logarithmique.

Simulation of automatic optimization of harmonic energy backscattered by the microbubble by iterative search of frequencies $f_{1}$ and $f_{2}$ of half-sines truncated. The pressure level $A_{0}$ was $240 \mathrm{kPa}$. The dashed line corresponded to maximal harmonic energy when $f_{1}$ was equal to $f_{2}$. The dash-dot line was the harmonic energy when the system was non-optimized such as $f_{1}=f_{2}=f_{0}$. The energy unity was an arbitrary unity (u.a.) with a energy dimension and a log scale.

fusées par le tissu. Pour l'instant, le moyen le plus simple pour réduire l'impact des harmoniques tissulaires est de baisser le niveau de pression émis.

De plus, cette fonction de coût est, en absolue, indépendante du modèle de simulation, puisque elle ne prend en compte, de façon itérative, que les mesures des signaux en entrée et en sortie de la chaîne.

Les mesures empiriques de la fonction de coût ont montrées la présence d'un seul maxi- tered by the tissue. For now, the easiest way to reduce the impact of tissue harmonics is to lower the level of pressure transmitted.

Moreover, this cost function is, in absolute terms, independent of the simulation model, since it only takes into account iteratively the measurements of the input and output signals of the chain.

The empirical measurements of the cost function showed the presence of a single glo- 
mum global, ce qui a facilité la recherche automatique de l'optimum. Il est clair qu'en pratique rien ne garantit la convexité de notre fonction de coût, ce problème pouvant être résolu en remplaçant l'algorithme du gradient par un autre algorithme plus robuste. Notez toutefois que lors de notre travail précédent [17], un simple algorithme du gradient avait suffit. Cet algorithme possède une vitesse de convergence qui nous semble adaptée pour des expérimentations. Une implémentation en temps-réel est envisageable puisque le temps de calcul est négligeable. Toutefois, si la vitesse de convergence n'était pas suffisante, d'autres algorithmes, comme par exemple celui de Newton-Raphson, peuvent être utilisés.

Enfin, un inconvénient non négligeable de notre méthode est qu'il faudra disposer d'un générateur de signaux analogique programmable pour réaliser les différentes expérimentations futures. Mais ce problème est en passe d'être résolu puisque les systémiers commencent à proposer de nouvelles générations d'imageur disposant de générateur programmable.

Pour conclure, notre méthode est une version optimisée de l'imagerie du second harmonique. Nous avons montré qu'elle maximise bien automatiquement l'énergie harmonique des microbulles et ceci sans connaissance a priori. Le gain obtenu dépend des propriétés du milieu et du système avec lequel il est étudié. Toutefois, dans le but de distinguer uniquement les harmoniques générées par les microbulles, il serait intéressant d'appliquer la méthode à une autre technique d'imagerie, comme l'imagerie par inversion d'impulsions. Ce travail est en cours et semble prometteur.

\section{Remerciements / Acknowledgments}

Ce travail a bénéficié du soutien financier de l'Agence Nationale de la Recherche dans le cadre du projet MONITHER (ANR07-TECSAN-015). bal maximum, which facilitated the automatic search for the optimum. It is clear that in practice nothing guarantees the convexity of our cost function, this problem being solvable by replacing the gradient algorithm by another more robust algorithm. Note, however, that in our previous work [17], a simple gradient algorithm was sufficient. This algorithm possesses a speed of convergence which seems to us suitable for experiments. A realtime implementation is conceivable, since the calculation time is negligible. However, if the rate of convergence was not sufficient, other algorithms, such as Newton-Raphson method, may be used.

Finally, a significant disadvantage of our method is that it will be necessary to have a programmable analogue signal generator to carry out the various future experiments. But this problem is about to be solved since the manufacturers are starting to propose new generations of ultrasound scanner having programmable generator.

To conclude, our method is an optimized version of second harmonic imaging. We have shown that it automatically maximizes the microbubble harmonic energy without knowledge a priori. The gain obtained depends on the properties about the medium and about the system with which it is studied. However, in order to distinguish only the harmonics generated by the microbubbles, it would be useful to apply the method to another imaging technique, such as pulse inversion imaging. This work is ongoing and looks promising.

This work benefited from the financial support of the French National Research Agency (ANR) under the MONITHER project (ANR07-TECSAN-015).

[1] P. J. A. Frinking, A. Bouakaz, J. Kirkhorn, F. J. Ten Cate, N. de Jong, Ultrasound Contrast Imaging : Current and New Potential Methods, Ultrasound Med. Biol. 26 (6) (2000) 965975. 
[2] D. Cosgrove, Ultrasound Contrast Agents : An Overview, European Journal of Radiology 60 (3) (2006) 324-330.

[3] J. M. G. Borsboom, A. Bouakaz, N. de Jong, Pulse Subtraction Time Delay Imaging Method for Ultrasound Contrast Agent Detection, IEEE Trans. Ultrason., Ferroelectr., Freq. Control 56 (6) (2009) 1151-1158.

[4] J. M. G. Borsboom, C. T. Chin, N. de Jong, Nonlinear Coded Excitation Method for Ultrasound Contrast Imaging, Ultrasound Med. Biol. 29 (2) (2003) 277-284.

[5] T. G. Leighton, The Acoustic Bubble, Londres, Royaume-Uni, 1994.

[6] P. N. Burns, Instrumentation for Contrast Echocardiography, Echocardiography 19 (3) (2002) 241-258.

[7] F. Forsberg, W. T. Shi, B. B. Goldberg, Subharmonic Imaging of Contrast Agents, Ultrasonics 38 (1-8) (2000) 93-98.

[8] A. Bouakaz, S. Frigstad, F. J. Ten Cate, N. de Jong, Super Harmonic Imaging : A New Imaging Technique for Improved Contrast Detection, Ultrasound Med. Biol. 28 (1) (2002) $59-68$.

[9] M.-X. Tang, J.-M. Mari, P. N. T. Wells, R. J. Eckersley, Attenuation Correction in Ultrasound Contrast Agent Imaging : Elementary Theory and Preliminary Experimental Evaluation, Ultrasound Med. Biol. 34 (12) (2008) 1998-2008.

[10] D. H. Simpson, C. T. Chin, P. N. Burns, Pulse Inversion Doppler : A New Method for Detecting Nonlinear Echoes from Microbubble Contrast Agents, IEEE Trans. Ultrason., Ferroelectr., Freq. Control 46 (2) (1999) 372-382.

[11] G. A. Brock-fisher, M. D. Poland, P. G. Rafter, Means for increasing sensitivity in non-linear ultrasound imaging systems, U.S. Patent 5577505 (1996).

[12] P. Phillips, E. Gardner, Contrast-Agent Detection and Quantification, Eur. Radiol. 14 (2004) 4-10.

[13] R. J. Eckersley, C. T. Chin, P. N. Burns, Optimising Phase and Amplitude Modulation Schemes for Imaging Microbubble Contrast Agents at Low Acoustic Power, Ultrasound Med. Biol. 31 (2) (2005) 213-219.

[14] V. Mahue, J. M. Mari, R. J. Eckersley, C. G. Caro, M.-X. Tang, Pulse subtraction Doppler, Physics Procedia 3 (1) (2010) 749-753.

[15] P. Phukpattaranont, E. S. Ebbini, Post-Beamforming Second-Order Volterra Filter for Pulse-Echo Ultrasonic Imaging, IEEE Trans. Ultrason., Ferroelectr., Freq. Control 50 (8) (2003) 987-1001.

[16] A. J. Reddy, A. J. Szeri, Optimal Pulse-Inversion Imaging for Microsphere Contrast Agents, Ultrasound Med. Biol. 28 (4) (2002) 483-494.

[17] S. Ménigot, A. Novell, I. Voicu, A. Bouakaz, J.-M. Girault, Adaptive Contrast Imaging : Transmit Frequency Optimization, Physics Procedia 3 (1) (2010) 667-676. 
[18] C. Greis, Technology Overview : SonoVue (Bracco, Milan), Eur. Radiol. Suppl. 14 (8) (2004) $11-15$.

[19] H. J. Vos, F. Guidi, E. Boni, P. Tortoli, Method for Microbubble Characterization Using Primary Radiation Force, IEEE Trans. Ultrason., Ferroelectr., Freq. Control 54 (7) (2007) $1333-1345$.

[20] H. J. Vos, F. Guidi, E. Boni, P. Tortoli, Acoustical Investigation of Freely Moving Single Microbubbles, in : Proc. of the IEEE Ultrasonic Symposium, vol. 2, 755-758, 2005.

[21] K. Chetty, C. A. Sennoga, J. V. Hainal, R. J. Eckersley, E. Stride, P1F-4 High Speed Optical Observations and Simulation Results of Lipid Based Microbubbles at Low Insonation Pressures, in : Proc. IEEE Ultrason. Symp., 1354-1357, 2006.

[22] L. Hoff, Acoustic Characterization of Contrast Agents for Medical Ultrasound Imaging, Kluwer Academic, Boston, USA, 2001.

[23] B. Widrow, S. Stearns, Adaptive Signal Processing, Prentice Hall, Englewood Cliffs, New Jersey, USA, 1985. 